\title{
SOME NOTES ON TILE DRAINAGE ON THE SOUTH COAST OF PORTO RICO
}

By G. M. Giles, Manager, Central Mercedita

The use of tile drains in Porto Rico was first attempted, so far as the writer knows, at the Mayaguiez Experiment Station some eight or ten years ago.

In 1921 while visiting that station a field was pointed out as having been drained several years previously. The drainage was so successful as to convert what had been a lagoon in wet weather, and a swamply soil in dry spells, into a fertile field which was planted to cane and was being cultivated by a wheeled cultivator. drawn by mules.

This experience seemed worth emulating and it was decided to try similar work at Mercedita where there are numerous wet spots in many fields. These spots are for the most part salty as well as wet, due to the evaporation of excess irrigation water which is more or less charged with salts from the alkaline soils in the neighborhoor.

On investigation it appeared that drain tile made in the States conld not be imported at reasonable cost on account of excessive breakage. A hand-power machine was therefore secured for making tile from cement mortar. These maehines are inexpensive and after a little practice an ordinary laborer with one helper can make from 250 to 350 tiles per day.

The mortar used is three-to-one mixture, and one bag of cement sliould make abont 75 tiles four inches in diameter and one foot loug.

After curing ten days or two weeks the tile can be handled and hauled to the field with but nominal breakage.

The depth and spacing of drains is a matter for experiment. In very wet impervious soils we have sometimes placed drains only $121 / 2$ feet apart. This was in low poyal land where the outlet was only $21 / 2$ feet lower than the surface of the field. In more favorable circumstances drains 100 feet apart and $31 / 2$ to $41 \% 2$ below the surface have been satisfactory. Not infrequently the depth and spacing rary considerably in the same field, owing to the difference in soil and in the amount of water to be removed.

It has been our practice to cover tile, which has been laid to grade, with from four to six inches of graval, to prevent entrance 
of silt and facilitate entrance of water. In very soft soil we have used a trough of one-inch lumber under the tile to preserve grade and prevent broken aligmment of tiles.

The use of the tile drains instead of open ditches has several, advantages. Tile drains once placed do not have to be cleaned as do open ditches. In only two or three instances have drains become clogged in our three-year experience, and it is believed that the useful life of the average drain will be at least ten years, probably nuch more.

The use of tile drains permits plowing and cultivation by animal power which is not possible when frequent open ditches are encountered.

The covered drains permit all of the surface to be used for planting. In some cases 25 per cent more cane can be planted in the same field.

With covered drains the cutting and hauling of the cane is faeilitated and none of the cane is lost by falling into open ditches.

\section{RESULTS}

The object of a well-designed system of drainage is to lower the ground water level, thus permitting aeration of the soil and, making available the plant food contained in that portion of the soil not previously reached by the feeding roots of the cane. This, in practice, makes available virgin soil to a depth in some cases of two or three feet. The effect is seen in the increased growth and production of the cane.

The first field drained by tile at Mercedita was planted to cane in September 1921, the wet part being plowed for the first time. Previous planting had been in holes made in the banks between ditches. The crop was harvested in 1923 with an average yield of 56 tons cane per acre. The previous record of this field was, 1917,11 tons per acre; 1918, 27 tons per acre; 1919, 21 tons per acre; 1920, 28 tons per acre; and 1921, 27 tons per acre.

Another illustration of the possibilities of drainage was furnishot by a field of low-lying land just east of Inabón River. This field was planted each year 1918-1919-1920 and nearly all the cane was killed by back water from the river each year.

In the summer of 1921 a dike was constructed to hold back the flood waters and a ditch made the inner side of the dike. Into this diteh drain tiles discharge the water from the filed, which is 
only 4 to 5 feet above sea level. Owing to latk of fall for natura! drainage the water is removed from the ditch by pumping it over the dike, alout 4 feet lift. The result was a crop averaging $4 \pi$ tons per acre on 20 acres of land that had given no crop from three previous plantings.

Similar instances can be multiplied from our own experiences and the work of installing tile drains in all fields that have required ditches is being pushed forward.

One of the inevitable consecuences of irrigation is the formation of wet spots in many fields when the subsoil does not provide natural outlet for the surplus water applied. These wet spots after a fer years become salty from the continued surface eraporation. Tile drainage offers a practicable means of remedying this condition and the earlier it is applied the better, since once the soil is thoroughly impregnated with salts it may take a number of years to remove the excess so that crops will grow again. Some of the earliest drains installed at Mercedita are still discharging saline water and part of the area drained will not produce cane, but these areas are growing smaller each year and we hope that within a few more rears, the whole will be reclaimed.

An example of this condition is a field near Hercedita factory which has a salty spot near its center. This portion of the field was not planted for some years of failure to produce.

Tile drains were placed in the wet portion in the spring of 1921. The previous record of the field was:

\begin{tabular}{|c|c|c|c|}
\hline-4 & cucralas & Gran Cultura & 40 tons per cacrala \\
\hline $919_{-}$ & cuc & Gran Cultura & ons jer cucrda \\
\hline 2 & enerd & Primavera & ms per cuerda \\
\hline-71 & 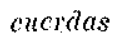 & Ratoons & 13 tons 1 er \\
\hline
\end{tabular}

After tiling the whole field 10 cucrdes were planted as but only $91 / 4$ acres were harvested, which gave a crop of 23 tous per acre in 1923 as gran cultura altho abont one-half acre had practically no cane on it. The arerage for the 10 acres was 37 tons. The non-productive portion is smaller and it is expected that in another year or two cane will be growing on the entire area. 